\title{
Peran Guru Pendidikan Agama Islam (PAI) Dalam Membina Pendidikan Karakter Peserta Didik
}

\author{
Solihin $^{1}$ \\ h.sholihin999@gmail.com \\ STAI Miftahul 'Ula Nganjuk
}

\begin{abstract}
Character education is a planned effort to make students know, care about, and internalize the noble values of the nation and religion, so that they become human beings (insan kamil).

Character education can be obtained well in formal education or non-formal education, Islamic religious education teachers are expected to be able to instill and foster character education for students. Some of the roles of Islamic religious education teachers in fostering student character education, including: First, fostering the character education based on religion, Second, fostering character education based on cultural values, Third, character education based on environment, and Fourth, character education based on self-potential. Islamic religious education teachers must be aware and understand that coaching is not only enough with orders, not only by giving rewards to those who carry out discipline, or giving punishment for violators, but more than that where coaching must be aware of the students themselves. When the awareness has emerged from the students, without coercion from the teacher, students will do habits and have an environment-based character. And it is at this stage that teachers are said to be successful in fostering character education.
\end{abstract}

Keywords: Islamic Education Teachers, Students, Character Education.

\section{A. Pendahuluan}

Pembangunan karakter yang merupakan upaya perwujudan amanat Pancasila dan Pembukaan UUD 1945 dilatarbelakangi oleh realita permasalahan kebangsaan yang berkembang saat ini, seperti: disorientasi dan belum dihayatinya nilai-nilai Pancasila; keterbatasan perangkat kebijakan terpadu dalam mewujudkan nilai-nilai Pancasila; bergesernya nilai etika dalam kehidupan berbangsa dan bernegara; memudarnya kesadaran terhadap nilai-nilai budaya bangsa; ancaman disintegrasi bangsa; dan melemahnya kemandirian bangsa. ${ }^{2}$ Sehingga pendidikan karakter dewasa ini semakin mendapat perhatian dari masyarakat Indonesia, terutama oleh kalangan akademisi dan pemerintah. Sikap dan perilaku masyarakat dan bangsa Indonesia sekarang cenderung mengabaikan nilai-nilai luhur yang sudah lama dijunjung tinggi dan mengakar dalam sikap dan perilaku sehari-hari. Nilai-nilai karakter mulia, seperti kejujuran,

\footnotetext{
${ }^{1}$ Dosen Tetap STAI Miftahul 'Ula Nganjuk

${ }^{2}$ Kemdiknas, Buku Induk Pembangunan Karakter. (Jakarta, 2010), 4
} 
kesantunan, kebersamaan, dan religius, sedikit demi sedikit mulai tergerus oleh budaya asing yang cenderung hedonistik, materialistik, dan individualistik, sehingga nilai-nilai karakter tersebut tidak lagi dianggap penting jika bertentangan dengan tujuan yang ingin diperoleh.

Mencerdaskan kehidupan bangsa sebagai salah satu icon penting kehidupan masyarakat perlu dilakukan upaya-upaya aktualisasi menuju masa depan yang lebih baik. Sebagaimana yang dicita-citakan pendiri bangsa (founding fathers) Indonesia, salah satunya adalah pendidikan di mana dengan pendidikan dapat mengembangkan bakat seseorang sampai pada tingkat optimal dalam batas hakikat individu, dengan tujuan supaya tiap manusia bisa secara terhormat ikut serta dalam pengembangan manusia dan masyarakatnya terus menerus mencapai martabat kehidupan yang lebih tinggi. ${ }^{3}$ Salah satunya dengan pembinaan pendidikan karakter pada peserta didik, di mana dengan pendidikan karakter, maka peserta didik dapat mengembangkan kecerdasan intelektualnya, kecerdasan emosional serta kecerdasan sosialnya.

Nilai dasar atau karakter dasar yang ditanamkan dalam pendidikan karakter adalah tiga komponen karakter (components of good character) yaitu pengetahuan tentang moral (moral knowing), perasaan tentang moral (moral feeling), dan perbuatan bermoral (moral actions)" 4 Sehingga dalam pembinaannya diperlukan peran dari berbagai pihak, baik dari pendidik, pengambil kebijakan (pemerintah) maupun dari masyarakat umum serta waktu yang panjang. Pendidikan karakter merupakan pilar penting bagi kemajuan bangsa. Karakter yang tertanam kuat dari setiap individu akan menjadikan peserta didik selalu memilki prinsip hidup dan selalu bersikap positif dan pada akhirnya menjadi generasi yang berguna bagi nusa dan bangsa, sebaliknya jika peserta didik tidak memiliki karakter, maka akan menjadi sulit untuk memiliki prinsip hidup, serta tidak dapat berbuat banyak unutk nusa dan bangsa. Apalagi hari ini dunia, sedang dihadapkan ancaman globalisasi, ancaman yang memerlukan orang-orang yang tangguh untuk menghadapinya.

Pendidikan karakter dapat diperoleh baik di pendidikan formal maupun pendidikan non formal. Salah satu jenis pendidikan formal adalah sekolah. Usaha pemerintah untuk meningkatkan sumber daya manusia adalah dengan mewajibkan sekolah 9 tahun. Namun dalam perkembangannya, kehidupan peserta didik saat ini dihadapkan pada berbagai masalah yang

\footnotetext{
${ }^{3}$ Musthofa Rembagy, Pendidikan Transformatif Pergulatan Kritis merumuskan pendidikan di Tengah Pusaran Arus Globalisasi,(Yokyakarta: Teras, 2008), 4

${ }^{4}$ Nurul Zuriah, Pendidikan Moral \& Budi Pekerti Dalam Perspektif Perubahan, (Jakarta: Bumi Aksara, 2008), 45
} 
kompleks dan perlu mendapatkan perhatian serius, diantaranya semakin menurunnya tatakrama kehidupan sosial dan etika moral dalam praktik kehidupan. Pelanggaran moral tidak dapat dipisahkan dari peserta didik, terutama mereka yang berada pada tingkatan Sekolah Menengah Atas (SMA) atau sedrajat. Pelanggaran-pelanggaran yang mereka lakukan tentu didorong atas berbagai motivasi, salah satu tujuan mereka melakukan pelanggaran adalah untuk mencari atau mendapat perhatian dari teman, guru dan orang tua mereka, tidak jarang juga mereka melakukannya hanya karena ingin menunjukkan eksistensinya di lingkungan sekolah.

Mengingat bahwa pendidikan sebagai hak asasi setiap individu anak bangsa seperti yang tertuang dalam UUD 1945 Pasal 31 ayat (1) yang menyebutkan bahwa setiap warga negara berhak mendapatkan pendidikan. ${ }^{5}$ Serta pentingnya pendidikan karakter untuk mengembangkan kecerdasan peserta didik, serta sentralnya peran seorang guru PAI (Pendidikan Agama Islam) dalam pembinaan pendidikan karakter peserta didik. Di mana guru PAI erat kaitannya dengan pembinaan kecerdasan intelektual, emosional serta sosial peserta didik, hal ini karena guru PAI mengampu mata pelajaran berbasis kurikulum formal serta bersentuhan langsung dengan peserta didik. Oleh karena itu guru PAI diharapkan mampu mengajarkan, membimbing, dan memberikan tauladan yang baik kepada peserta didik tentang bagaimana berperilaku yang baik, agar mereka memiliki karakter sebagaimana idealnya seorang peserta didik, baik karakter kognitif, karakter afektif, maupun karakter sosial.

Berdasarkan uraian diatas, penulis tertarik untuk mengkaji lebih jauh lagi tentang peran guru PAI dalam penanaman dan pembinaan pendidikan karakter peserta didik, yang peneliti rumuskan dalam judul "Peran Guru Pendidikan Agama Islam (PAI) Dalam Membina Pendidikan Karakter Peserta Didik".

\section{B. Kajian Pendidikan Karakter}

1. Pengertian Pendidikan Karakter

Menurut Ahmad D. Marimba pendidikan adalah bimbingan atau pimpinan secara sadar oleh si pendidik terhadap perkembangan jasmani dan rohani si terdidik menuju terbentuknya kepribadian yang utama. Lebih jauh dikemukakan bahwa unsur-unsur yang terdapat dalam pendidikan adalah: a) usaha (kegiatan) usaha itu bersifat bimbingan (pimpinan atau

${ }^{5}$ Undang-Undang Sistem Pendidikan Nasional Tahun 2003 (UU RI Nomor 20 Tahun 2003), Jakarta: Sinar Grafika, 2003), 13 
pertolongan) dan dilakukan secara sadar, b) ada pendidik, pembimbing atau penolong, c) ada yang didik atau si terdidik, d) bimbingan itu mempunyai dasar dan tujuan, e) dalam usaha itu tentu ada alat-alat yang dipergunakan. ${ }^{6}$ Sedangkan Ki Hadjar Dewantara menyatakan bahwa pendidikan adalah daya upaya untuk memajukan budi pekerti, pikiran, dan jasmani anak agar selaras dengan alam dan masyarakatnya. ${ }^{7}$

Sementara dalam Undang-undang Sisdiknas dikemukakan bahwa pendidikan adalah usaha sadar dan terencana untuk mewujudkan suasana belajar dan proses pembelajaran agar peserta didik secara aktif mengembangkan potensi dirinya untuk memiliki kekuatan spiritual keagamaan, pengendalian diri, kepribadian, kecerdasan, akhlak mulia, serta keterampilan yang diperlukan dirinya, masyarakat, bangsa, dan negara. ${ }^{8}$ Dari beberapa pengertian tentang pendidikan di atas, dapat ditarik kesimpulan bahwa pendidikan dapat diartikan sebagai usaha manusia untuk membina kepribadiannya sesuai dengan nilai-nilai dalam masyarakat dan kebudayaan. Pengertian pendidikan mengalami perkembangan, meskipun secara essensial tidak jauh berbeda.

Menurut Ramli, pendidikan karakter memiliki esensi dan makna yang sama dengan pendidikan moral dan pendidikan akhlak. Tujuannya adalah membentuk pribadi anak, supaya menjadi manusia yang baik, warga masyarakat yang baik, dan warga Negara yang baik. Adapun kriteria manusia yang baik, warga masyarakat yang baik , dan warga Negara yang baik bagi suatu masyarakat atau bangsa, secara umum adalah nilai-nilai sosial tertentuyang banyak dipengaruhi oleh budaya masyarakat dan bangsanya. Oleh karena itu, hakikat pendidikan karakter dalam konteks pendidikan Indonesia adalah pendidikan nilai, yakni pendidikan nilai-nilai luhur yang bersumber dari budaya bangsa Indonesia sendiri, dalam rangka membina kepribadian generasi muda. ${ }^{9}$

Pendidikan karakter juga dapat dimaknai sebagai upaya yang terencana untuk menjadikan peserta didik mengenal, peduli, dan menginternalisasikan nilai-nilai luhur bangsa dan agama, sehingga peserta didik menjadi insan kamil. Pendidikan karakter juga dapat diartikan sebagai suatu sistem penanaman nilai-nilai karakter kepada warga sekolah yang

\footnotetext{
${ }^{6}$ Hasbullah, Dasar-Dasar Ilmu Pendidikan, (Jakarta: PT. RajaGrafindo Persada, 1999), 3

${ }^{7}$ Ki Hadjar Dewantara. Pendidikan. (Yogyakarta: Majelis Luhur Persatuan Taman Siswa), 14

8 Undang-Undang Sistem Pendidikan Nasional Tahun 2003 (UU RI Nomor 20 Tahun 2003), Jakarta: Sinar Grafika, 2003), 2

${ }^{9}$ Heri Gunawan, Pendidikan Karakter Konsep dan Implementasi, (Bandung:Alfabeta, 2012) ,23- 24.
} 
meliputi komponen pengetahuan, kesadaran atau kemauan dan tindakan untuk melaksanakan nilai-nilai tersebut baik terhadap Tuhan Yang Maha Esa, diri sendiri, sesama, lingkungan maupun kebangsaan sehingga menjadi manusia yang sempurna. Sehingga dapat diambil kesimpulan bahwa pendidikan karakter adalah proses menanamkan karakter tertentu sekaligus memberi benih agar peserta didik mampu menumbuhkan karakter khasnya pada saat menjalankan kehidupan, menghadapi setiap perubahan zaman.

2. Fungsi Pendidikan Karakter

Fungsi pendidikan menurut Hasan Langgulung seara garis besar dibagi pada tiga. Pertama, menyiapkan generasi muda untuk memiliki kemampuan agar bisa memegang peranan-peranan pada masa yang akan datang di tengah kehidupan masyarakat. Kedua, memindahkan ilmu pengetahuan yang berkaitan dengan peranan dari generasi tua ke generasi muda. Ketiga, memindahkan nilai-nilai generasi tua ke generasi muda dengan tujuan agar keutuhan dan kesatuan masyarakat terpelihara, sebagai syarat utama berlangsungnya kehidupan suatu masyarakat dan juga peradaban. ${ }^{10}$

Sedangkan menurut Kementerian Pendidikan Nasional fungsi pendidikan karakter adalah: 1) pengembangan: pengembangan potensi peserta didik untuk menjadi pribadi berperilaku baik; ini bagi peserta didik yang telah memiliki sikap dan perilaku yang mencerminkan budaya dan karakter bangsa; 2) perbaikan: memperkuat kiprah pendidikan nasional untuk bertanggung jawab dalam pengembangan potensi peserta didik yang lebih bermartabat; dan 3) penyaring: untuk menyaring budaya bangsa sendiri dan budaya bangsa lain yang tidak sesuai dengan nilai-nilai budaya dan karakter bangsa yang bermartabat.

Pendidikan karakter berfungsi (1) membangun kehidupan kebangsaan yang multikultural; (2) membangun peradaban bangsa yang cerdas, berbudaya luhur, dan mampu berkontribusi terhadap pengembangan kehidupan ummat manusia; mengembangkan potensi dasar agar berhati baik, berpikiran baik, dan berperilaku baik serta keteladanan baik; (3) membangun sikap warganegara yang cinta damai, kreatif, mandiri, dan mampu hidup berdampingan dengan bangsa lain dalam suatu harmoni.

3. Jenis-jenis Pendidikan Karater

${ }^{10}$ H.A.R Tilaar, Pendidikan Dalam Pembangunan Nasional Menyongsong Abad XXI, (Jakarta: Balai Pustaka, 1990), 59 
Jenis-jenis Pendidikan Karakter Ada empat jenis karakter yang selama ini dikenal dan dilaksanakan dalam proses pendidikan, yaitu:

1) Pendidikan karakter berbasis nilai religius, yang merupakan kebenaran wahyu tuhan (konservasi moral).

2) Pendidikan karakter berbasis nilai budaya, antara lain yang berupa budi pekerti, pancasila, apresiasi sastra, keteladanan tokoh-tokoh sejarah dan para pemimpin bangsa.

3) Pendidikan karakter berbasis lingkungan (konservasi lingkungan).

4) Pendidikan karakter berbasis potensi diri, yaitu sikap pribadi, hasil proses kesadaran pemberdayaan potensi diri yang diarahkan untuk meningkatkan kualitas pendidikan. ${ }^{11}$

4. Pendidikan Karakter dan Pendidikan Akhlak

Pendidikan Akhlak, mengenai penjelasan akhlak secara luas, banyak sekali tokoh yang memberikan pengertian secara bervariasi. Diantaranya M. Abdullah Darraz, menurut beliau akhlak adalah sesuatu kekuatan dalam kehendak yang mantap, kekuatan dan kehendak mana berkombinasi membawa kecenderungan pada pemilihan pihak yang benar (akhlak yang baik) atau pihak yang jahat (akhlak yang jahat). ${ }^{12}$

Pendidikan akhlak sebagaimana dirumuskan oleh Ibn Miskawaih dan dikutip oleh Abudin Nata, merupakan upaya ke arah terwujudnya sikap batin yang mampu mendorong secara spontan lahirnya perbuatan-perbuatan yang bernilai baik dari seseorang. Dalam pendidikan akhlak ini, kreteria benar dan salah untuk menilai perbuatan yang muncul merujuk kepada Al-Qur'an dan Sunah sebagai sumber tertinggi ajaran Islam. Dengan demikian maka pendidikan akhlak bisa dikatakan sebagai pendidikan karakter dalam diskursus pendidikan Islam.

Dalam Islam sendiri, yang menjadi dasar atau landasan pendidikan akhlak manusia adalah al-Qur'an dan al-Sunnah. Segala sesuatu yang baik menurut al-Qur'an dan alSunnah, itulah yang baik dijadikan pegangan dalam kehidupan sehari-hari. Sebaliknya, segala sesuatu yang buruk menurut al-Qur'an dan al-Sunnah, berarti tidak baik dan harus dijauhi. ${ }^{13}$ Dalam kaitannya dengan pendidikan akhlak, terlihat bahwa pendidikan karakter

${ }^{11}$ Yahya Khan, Pendidikan Karakter Berbasis Potensi Diri; Mendongkrak Kualitas Pendidikan, (Yogyakarta, Pelangi Publishing, 2010), 2

${ }^{12}$ Erwin Yudi Prahara, Materi Pendidikan Agama Islam (Ponorogo: STAIN Po Press, 2009), 182.

${ }^{13}$ Rosihan Anwar, Akhlak Tasawuf (Bandung: Pustaka Setia, 2010), 20. 
mempunyai orientasi yang sama dengan pendidikan akhlak yaitu pembentukan karakter. Perbedaan bahwa pendidikan akhlak terkesan timur dan Islam sedangkan pendidikan karakter terkesan Barat dan sekuler, bukan alas an yang dipertentangkan. Pada kenyataannya keduanya memiliki ruang untuk saling mengisi.

Melalui gabungan dua paradigma ini, pendidikan karakter akan bisa terlihat dan berhasil bila kemudian seorang peserta didik tidak akan hanya memahami pendidikan nilai sebagai sebuah bentuk pengetahuan, namun juga menjadikannya sebagai bagian dari hidup dan secara sadar hidup berdasar pada nilai tersebut. ${ }^{14}$ Pada dasarnya untuk memiliki karakter peserta didik memerlukan pembinaan dari pendidik, salah satunya dengan pembinaan karakter karakter berbasis nilai religius, berbasis nilai budaya, berbasis lingkungan serta berbasis potensi diri.

\section{Tenaga Pendidik (Guru PAI)}

Pendidikan Agama Islam (PAI) di Indonesia sebagai sub sistem pendidikan Nasional, mempunyai peran yang sama dengan pendidikan pada umumnya, dalam proses pembangunan Nasional. Pendidikan Agama Islam mempunyai peranan penting dalam pembangunan nasional, yaitu dalam rangka pembentukan manusia Indonesia seutuhnya, yaitu manusia yang beriman dan bertaqwa kepada Tuhan Yang Maha Esa. ${ }^{15}$

Guru adalah pendidik, yang menjadi contoh, panutan, dan identifikasi bagi para peserta didik dan lingkungannya. Oleh karena itu, guru harus memiliki standar kualitas pribadi tertentu, yang tidak hanya mencakup mentrasfer ilmu pengetahuan ke peserta didik, akan tetapi juga merupakan figur keteladanan dan tokoh yang akan ditiru dan diikuti langkahnya. Untuk itu kita harus membekali generasi muda kita bukan hanya dengan pengetahuan dan keterampilan saja, tetapi juga dengan integritas moral dan iman. Karena pendidikan merupakan integral dari kegiatan pendidikan, juga masa depan, maka etika dan agama perlu dipelajari.

Di dalam UUSPN No. 2/1989 pasal 39 ayat (2) ditegaskan bahwa isi kurikulum setiap jenis, jalur, dan jenjang pendidikan wajib memuat, antara lain pendidikan agama. Dan dalam penjelasannya dinyatakan bahwa pendidikan agama merupakan usaha untuk memperkuat iman

\footnotetext{
${ }^{14}$ Marfu', Perbedaan pendidikan karakter dengan pendidikan akhlak, pendidikan moral, dan pendidikan nilai, http:// risetpendidikangmarfu'.com, Diakses pada tanggal 20 September 2018.

15 Muhaimin, Paradigma Pendidikan Islam; Upaya pengefektifan PAI di Sekolah, (Bandung: PT Remaja Rosdakarya, 2002), 75
} 
dan ketaqwaan terhadap Tuhan Yang Maha esa sesuai dengan agama yang dianut oleh peserta didik yang bersangkutan dengan memperhatikan tuntutan untuk menghormati agama lain dalam hubungan kerukunan antar umat beragama dalam masyarakat untuk mewujudkan persatuan nasional. ${ }^{16}$

Dari pernyataan diatas dapat diketahui bahwa guru pendidikan agama Islam adalah guru yang mengajar mata pelajaran agama (Islam) yakni pendidikan yang berdasarkan pada pokokpokok, kajian-kajian dan asas-asas mengenai keagamaan Islam. Berdasarkan pengertian diatas dapat kita ketahui bahwa guru bukan hanya sekedar pemberi ilmu pengetahuan kepada anak didiknya, tetapi merupakan salah satu sumber ilmu dan moral yang akan membentuk seluruh pribadi anak didiknya, menjadi manusia yang berkepribadian mulia. ${ }^{17}$

\section{Peserta Didik}

Dalam proses pendidikan, peserta didik merupakan salah satu komponen manusiawi yang menempati posisi sentral, peserta didik menjadi pokok persoalan dan tumpuan perhatian dalam semua proses transformasi yang disebut pendidikan. Sebagai salah satu komponen penting dalam sistem pendidikan, peserta didik sering disebut seabagai bahan mentah (Raw Material).

Dalam perspektif psikologi peserta didik adalah individu yang sedang berada dalam proses pertumbuhan dan perkembangan baik fisik maupun psikis menurut fitrahnya masing-masing. Sebagai individu yang tengah tumbuh dan berkembang, peserta didik memerlukan bimbingan dan pengarahan yang konsisten menuju ke arah titik optimal kemampuan fitrahnya. ${ }^{18}$ Dalam prespektif modern peserta didik berstatus sebagai subjek didik oleh karenanya, peserta didik adalah subjek atau pribadi yang otonom yang ingin diakui keberadaannya. Selaku pribadi yang memiliki ciri khas dan otonomi ia ingin mengembangkan diri secara terus menerus guna memecahkan masalah-masalah hidup yang dijumpai sepanjang hidupnya. Ciri khas seorang peserta didik yang perlu dipahami oleh seorang pendidik ialah sebagai berikut:

a. Individu yang memiliki potensi fisik dan psikis yang khas sehingga merupakan insan yang unik.

b. Individu yang sedang berkembang.

c. Individu yang membutuhkan bimbingan individual dan perlakukan manusiawi.

\footnotetext{
${ }^{16}$ UU No 2 Tahun 1989-Sistem Pendidikan Nasional

${ }^{17}$ Muhaimin, Paradigma Pendidikan Islam..., 78

${ }^{18}$ Desmita, Psikologi Perkembangan Peserta Didik, (Bandung: PT. Remaja Rosdakarya, 2012), 39
} 
d. Individu yang memiliki kemampuan untuk mandiri. ${ }^{19}$

Beberapa ciri khas peserta didik tersebut di atas harus diketahui dan dipahami secara mendalam oleh seorang pendidik sehingga dengan begitu ia dapat mengatur kondisi dan strategi yang sesuai dengan kebutuhan peserta didik. Peserta didik merupakan seorang yang memiliki potensi dasar yang perlu dikembangkan melalui pendidikan baik secara fisik maupun psikis baik melalui pendidikan formal maupun informal,baik yang didapat melalui keluarga, lingkungan maupun sekolah.

Adapun peserta didik akan mengalami perkembangan sebagaimana berikut: ${ }^{20}$

a. Perkembagan Fisik

Manusia terdiri dari fisik dan psikhis. Fisik merupakan tempat berkembang berbagai perkembangan manusia. Di dalam fisik terjadi perkembangan kognitif, sosial, moral, agama, dan bahasa. Fisik merupakan tempat bagi perkembangan psikis manusia.

Pertumbuhan fisik manusia dipengaruhi faktor internal dan eksternal, sehingga bayi kembar sekalipun tidak memiliki irama perkembangan fisik yang sama, jika tumbuh dan berkembang dalam lingkungan yang berbeda. Persamaan gen tidak menjamin seseorang secara fisik akan tumbuh dan berkembang dengan pola yang sama dengan yang lainnya. Demikian juga kesamaan lingkungan juga tidak menyebabkan seseorang akan tumbuh dan berkembang secara fisik sama dengan teman sebayanya. Terjadi interaksi yang cukup intens antara faktor internal dan eksternal dalam pertumbuhan dan perkembangan fisik manusia.

b. Perkembangan Kognitif

Gardner menyatakan kemampuan kognitif adalah kemampuan menciptakan karya. Di dalam ajaran Islam dijelaskan bahwa manusia pada saat dilahirkan tidak mengetahui apapun, tetapi Allah membekalinya dengan kemampuan penginderaan dan hati untuk mendapatkan pengetahuan. Penjelasan ini dapat ditemui dalam Alquran surat anNahl/16: 78, yang artinya:

"Dan Allah mengeluarkan kamu dari perut ibumu dalam Keadaan tidak mengetahui sesuatupun, dan Dia memberi kamu pendengaran, penglihatan dan hati, agar kamu bersyukur".

\footnotetext{
${ }^{19}$ Umar Tirtahardja da Lasula, Pengantar Pendidikan Cetakan Ke-I, (jakarta: Rineka Cipta, 2000), 52-53

${ }^{20}$ Di sarikan dari Masganti, Perkembangan Peserta Didik (Medan: Kelompok Penerbit Perdana Mulya Sarana, 2012).
} 
Ibnu Katsir menafsirkan ayat ini bahwa kemampuan mendengar, melihat, dan berpikir manusia berkembang secara bertahap. Semakin dewasa seseorang semakin berkembang kemampuannya mendengar, melihat, dan akalnya akan semakin mampu membedakan baik dan buru, benar dan salah. Hikmah diciptakan kemampuan berpikir manusia secara bertahap agar dia mampu menjalankan ketaatannya kepada Tuhan.

Perkembangan kognitif manusia berkaitan dengan kemampuan mental dan fisik untuk mengetahui objek tertentu, memasukkan informasi ke dalam pikiran, mengubah pengetahuan yang telah ada dengan informasi yang baru diperoleh, dan perubahan tahapan-tahapan berpikir.

c. Perkemabangan Sosial

Perkembangan sosial merupakan kematangan yang dicapai dalam hubungan sosial. Perkembangan sosial dapat pula diartikan sebagai proses belajar untuk menyesuaikan diri terhadap norma-norma kelompok, moral, dan tradisi serta meleburkan diri menjadi satu kesatuan dan saling berkomunikasi dan kerja sama. Di dalam Islam manusia memiliki tanggung jawab sosial yang berat. Di dalam Alquran surat al-Baqarah/2: 30 dinyatakan yang artinya:

"Ingatlah ketika Tuhanmu berfirman kepada Para Malaikat: "Sesungguhnya aku hendak menjadikan seorang khalifah di muka bumi." mereka berkata: "Mengapa Engkau hendak menjadikan (khalifah) di bumi itu orang yang akan membuat kerusakan padanya dan menumpahkan darah, Padahal Kami Senantiasa bertasbih dengan memuji Engkau dan mensucikan Engkau?" Tuhan berfirman: "Sesungguhnya aku mengetahui apa yang tidak kamu ketahui."

Ibnu Katsir menafsirkan ayat ini dengan mengutip pendapat Qurthubi menyatakan dalil ini mewajibkan manusia mengangkat pimpinan untuk ketertiban sosial. Kehadiran seorang khalifah akan memungkinkan terjadi sikap tolong menolong manusia dari perilaku sewenang-wenang yang dilakukan orang yang zalim, memutuskan sengketa di antara manusia, menegakkan hukuman, dan memelihara keadilan. 
d. Perkemabangan Emosi

Perkembangan emosional dan intelektual biasanya berjalan beriringan untuk membantu anak mengembangkan kemampuan sosialnya, karena interaksi antara anakanak dan orang dewasa menciptakan kesehatan emosional. Perbedaan antara perasaan positif dan negatif terhadap situasi tertentu mungkin disebabkan perkembangan emosional. Remaja usia 12-18 tahun sejalan dengan perkembangan kognitifnya telah mampu menerjemahkan situasi sosial yang tepat untuk mengekspresikan emosi.

e. Perkembangan Moral

Perkembangan moral adalah perkembangan yang berkaitan dengan kemampuan seseorang untuk mengetahui baik dan buruk suatu perbuatan, kesadaran untuk melakukan perbuatan baik, kebiasaan melakukan baik, dan rasa cinta terhadap perbuatan baik. Moral berkembang sesuai dengan usia anak.

f. Perkembangan Agama

Jika perkembangan moral anak tidak terjadi sejak lahir, perkembangan agama pada anak menurut ajaran Islam telah ada sejak anak lahir. Fitrah beragama dalam diri manusia merupakan naluri yang menggerakkan hatinya untuk melakukan perbuatan "suci" yang diilhami oleh Tuhan Yang Maha Esa telah ada dalam diri anak sejak dia berada di tulang sulbi orang tuanya.

Di dalam tafsir Yusuf Ali dinyatakan bahwa fitrah Allah artinya ciptaan Allah. Manusia diciptakan Allah mempunyai naluri beragama yaitu agama tauhid. Jika kemudian ada manusia tidak beragama tauhid, maka hal itu tidaklah wajar, sebab melawan fitrahnya. Mereka tidak beragama tauhid itu hanya karena pengaruh lingkungan.

\section{E. Peran Guru PAI Dalam Pembinaan Pendidikan Karakter Peserta Didik}

Pada dasarnya tidak hanya lingkungan sekolah yang menjadi pusat penanaman dan pembinaan pendidikan karakter namun keluarga, lingkungan sekitar, masyarakat dan pemerintah pula ikut berperan aktif dalam mendukung hal tersebut, dengan tujuan terbentuknya peserta didik yang berkarakter baik dan unggul berdasarkan nilai-nilai luhur bangsa dan agama. Namun setidaknya lingkungan sekolah sebagai lingkungan pendidikan formal dan serta waktu peserta 
didik banyak dihabiskan di sekolah, sehingga lingkungan sekolah memiliki peran penting dalam pembinaan pendidikan karakter perserta didik.

Guru PAI memegang peranan penting dalam pembinaan pendidikan karakter, karena materi yang diajarkan selalu menekankan bagaimana peserta didik memenuhi kewajibannya sebagai hamba Allah S.W.T. Dalam upaya pembinaan pendidikan karakter, guru PAI hendaknya mengacu pada ketentuan sekolah yang berlaku, karena guru PAI merupakan "tangan panjang” dari pihak sekolah. Guru PAI tidak berjalan sendiri, tetapi merupakan bagian dari manajemen sekolah, sehingga upaya-upaya yang dilakukan oleh guru PAI merupakan perwujudan dari manajamen sekolah dalam pembinaan pendidikan karakter peserta didik. Beberapa peran guru PAI dalam pembinaan pendidikan karakter peserta didik, antara lain:

1 Pembinaan Pendidikan Karakter Berbasis Religius

Pendidikan agama adalah pendidikan yang memberikan pengetahuan dan membentuk sikap, kepribadian, serta ketrampilan peserta didik dalam mengamalkan ajaran agamanya, yang dilaksanakan sekurang-kurangnya melalui mata pelajaran/kuliah pada semua jalur, jenjang dan jenis pendidikan. Pendidikan agama berfungsi membentuk manusia Indonesia yang beriman dan bertaqwa kepada Tuhan Yang Maha Esa serta berakhlak mulia dan mampu menjaga kedamaian dan kerukunan, hubungan inter dan antar umat beragama.

Demikian halnya di Sekolah, pembinaan karakter berbasis pendidikan agama yang dikembangkan berpijak dari visi dan misi yang dikembangkan oleh sekolah, dengan kakrakter berbasis religius diharapkan setelah peserta didik lulus sekolah, memiliki profesional religius serta faham akan agama. Dan utamanya saat mereka kembali kemasyarakat atau saat mereka melanjutkan studi mereka dapat menerapkan ilmu yang telah didapat selama di Sekolah.

Adapun cara pembinaan yang digunakan oleh guru PAI antara lain;

1) Peningkatan Pendidikan Karakter (PPK), di imana setiap guru dalam setiap pembelajarannya, diwajibkan untuk menyisipkan materi tentang pendidikan karakter. Demikian halnya saat guru PAI menyampaikan materi pembelajaran, maka peningkatan pendidikan karakter, juga selalu ditekankan kepada peserta didik, hal ini bertujuan agar siswi tidak hanya memahami isi materi, namun juga dapat menerapkan prilaku-prilaku berdasarkan ajaran Islam.

2) Mendampingi ibadah sholat yang dapat dilakukan di Sekolah. Guru PAI dapat mendampingi peserta didik pada sholah dhuha atau sholat dzuhur, hal ini mengingat 
bahwa guru PAI tidak hanya berperan sebagai guru mata pelajaran, namun juga sebagai motivator, fasilitator dan evaluator, sehingga dalam pembinaan pendidikan karakter tidak hanya mengintruksikan kepada peserta didik untuk sholat berjamaah, namun juga mendampingi.

3) Menertibkan pembinaan doa malam dan sholat tahajud, selain didalam kelas, pembinaan karakter oleh guru PAI juga dapat dilakukan diluar kelas, salah satunya adalah pembinaan sholat malam, meskipun secara tidak langsung. Hal ini bertujuan agar peserta didik terbiasa melakukan ibadah sunnah, sehingga karakter berbasis religius benar-benar menjadi kebiasaan sehari-hari mereka.

\section{Pendidikan Karakter Berbasis Nilai Budaya}

Sebagai salah satu lembaga pendidikan yang berada dibawah naungan pemerintahan Republik Indonesia, maka pendidikan karakter berbasis budaya lokal serta nasionalisme tidak boleh ditinggalkan. Sedangkan cara guru PAI dalam pembinaan pendidikan karakter berbasis nilai budaya antara lain; Pertama, Pembiasaan Rutin, yaitu kegiatan yang dilakukan terjadwal, meliputi: upacara bendera setiap hari senin, doa bersama sebelum masuk kelas, ketertiban dalam berpakaian, pemeliharaan kebersihan (Jumat Bersih), kesehatan diri. Kedua, Pembiasaan Insidentil, yaitu kegiatan peserta didik yang tidak terjadwal, misalnya: pembentukan perilaku memberi senyum, salam, sapa kepada setiap warga yang ditemui, membuang sampah pada tempatnya, budaya antri, serta mengetuk pintuk saat hendak masuk kelas, kepedulian dengan teman sekolah. Ketiga, Pembiasaan Keteladanan, dalam bentuk perilaku sehari-hari, meliputi : berpakaian rapi dan sopan, bertuturkata yang baik, budaya membaca, serta datang tepat waktu (disiplin). Dengan kata lain, bahwa peran guru PAI dalam pembinaan pendidikan karakter tidak hanya di dalam kelas, namun juga di luar kelas. Hal ini bertujuan agar peserta didik memiliki performa yang baik, performa seorang ideal bagi seorang peserta didik.

3 Pendidikan Karakter Berbasis Lingkungan

Pendidika karakter berbasis lingkungan yang dikembangkan di sekolah memiliki tujuan secara umum agar peserta didik memilki kecintaan dan kepedulian kepada lingkungan dan sesama makhluk sosial, yang sudah merupakan kewajiban dari makhluk sosial. Dalam hal ini manajemen sekolah membantu peserta didik memahami perasaan orang lain. Kebajikan ini membuat peserta didik menjadi peka terhadap kebutuhan dan 
perasaan orang lain, mendorong untuk menolong orang yang kesusahan atau kesakitan, serta menuntut memperlakukan orang dengan kasih sayang. Adapun cara yang dapat digunakan oleh guru PAI dalam pembinaan pendidikan karakter berbasis lingkungan adalah kerja bakti lingkungan sekolah. Kerja bakti lingkungan dengan cara membersihkan lingkungan sekolah, baik di dalam dan di luar sekolah, kegiatan ini dapat dilakukan secara bersama-sama antara guru dengan siswa. Kerja bakti lingkungan bertujuan agar peserta didik memiliki sikap peduli terhadap lingkungan.

Guru PAI harus sadar dan paham bahwa pembinaan tidak hanya cukup dengan perintah, tidak hanya dengan pemberian reward bagi yang menjalankan disiplin, atau pemberian punishment bagi yang melanggar, namun lebih dari itu di mana pembinaan harus dapat memunculkan kesadaran dari peserta didik itu sendiri. Ketika kesadaran sudah muncul dari dalam diri peserta didik, maka tanpa adanya paksaan darii guru, peserta didik akan dengan sendirinya melakukan kebiasaan-kebiasaan dan memiliki karakter berbasis lingkungan. Dan ditahap inilah guru dikatakan berhasil dalam pembinaan pendidikan karakter.

4 Pendidikan Karakter berbasis Potensi Diri

Salah satu tugas dari suatu lembaga pendidikan adalah mengkesplorasi potensi peserta didik, dan hal ini juga yang seharusnya dilakukan oleh manjamen sekolah, termasuk melalui guru PAI. Pembinaan pendidikan berbasis potensi diri baik yang bersifat kognitif maupun psikomotorik. Adapun cara yang digunakan oleh guru PAI dalam pembinaan karakter berbasis potensi diri peserta didik antara lain;

1) Penggunaan metode pembelajaran yang inovatif, pengunaan metode ini bertujuan untuk menciptakan suasana kelas yang aktif. Guru PAI dalam mengampu mata pelajaran PAI, sesuai dengan struktur kurikulum alokasi waktu. Tidak adanya metode khusus yang dibebankan kepada guru PAI, memudahkan guru PAI dalam mengajar sesuai dengan gaya mengajar yang dimiliki. Karena tujuan akhirnya adalah bagaimana peserta didik dapat menyerap materi pembelajaran secara maksimal.

2) Cerdas Cermat PAI, kegiatan lomba ilmiah ini digunakan oleh guru PAI untuk menumbuhkan rasa kompetitif antar peserta didik, sehingga peserta didik berlombalomba untuk dapat memahami materi PAI yang telah diajarkan oleh guru baik didalam maupun diluar kelas. Terkadang memang dibutuhkan kompetisi untuk mendorong 
peserta didik berkeinginan belajar, karena tidak semua peserta didk memiliki sikap rajin belajar, maka dengan perlombaan diharapakan semua siswi mimilki semagat belajar.

3) Praktek materi PAI, cara ketiga untuk pembinaan karakter berbasis potensi diri adalah dengan mengadakan prakek materi PAI. Praktek diadakan untuk memantau sejauh mana peserta didik dapat mempraktekkan ibadah mahdoh, dan kegiatan praktek ini guru PAI akan menilai dan mengevaluasi praktek ibadah peserta didik. Cara ini sangat efektif untuk memperbaiki praktek ibadah para peserta didik, karena guru PAI secara langsung melihat praktek ibadah dari para siswi.

4) Ujian Praktek, pada setiap akhir semester guru PAI dapat mengadakan praktek ibadah. Hal ini bertujuan untuk mengevaluasi strategi pembinaan yang sudah dilalukan oleh guru PAI selama satu semester. Hasil daripada penilaiah terhadap praktek ibadah ini nantinya dapat dijadikan sebagai bahan pertimbangan dalam pelaksanaan pembinaan pendidikan karakter pada umumnya.

5) Hafalan bacaan Al-Qur'an, do'a-do'a dan dalil, cara terakhir adalah dengan memantau dan membimbing peserta didik untuk dapat mengahafalkan bacaan Al Qur'an, selain itu para peserta didik juga harus mampu menghafa do'a sehari-hari, hal ini agar peserta didik terbiasa berdo'a dengan do'a-do'a yang diajarakan oleh syariat Islam pada umumnya.

Program-program sekolah yang strategis untuk membangun karakter mulia telah dibuat secara rinci melalui peraturan dan tata tertib sekolah. Tata tertib ini menjadi dasar bagi para siswa dan selurus civitas sekolah (kepala sekolah, guru, karyawan, dan siapa pun) dalam beraktivitas sehari-hari di sekolah, termasuk dalam pembiaan pendidikan karakter. Dengan pembinaan Pendidikan Karakter diharapkan dapat membekali generasi bangsa dengan seperangkat pengetahuan (knowledge), sikap (disposition) yang berpangkal pada kebajikan (virtues) dengan sejumlah nilaimoral didalamnya serta keterampilan (skill), sebagai kompetensi yang dapat berkontribusi bagi eksistensi dan kemajuan hidup bangsa dan negara.

\section{F. Kesimpulan}

Guru PAI memegang peranan penting dalam pembinaan pendidikan karakter peserta didik, Beberapa peran guru PAI dalam pembinaan pendidikan karakter peserta didik, antara lain: 
Pertama, Pembinaan pendidikan karakter berbasis religius, dapat dilakukan dengan cara; (1) peningkatan pendidikan karakter (PPK), (2) mendampingi ibadah sholat yang dapat dilakukan di Sekolah, dan (3) pembinaan doa malam dan sholat tahajud sebagai ibadah tambahan. Kedua, Pembinaan pendidikan karakter berbasis nilai budaya, dapat diilakukan pendidikan karakter berbasis nilai budaya antara lain; (1) Pembiasaan Rutin, yaitu kegiatan yang dilakukan terjadwal, (2) Pembiasaan Insidentil, yaitu kegiatan peserta didik yang tidak terjadwal, dan (3) Pembiasaan Keteladanan, dalam bentuk perilaku sehari-hari. Ketiga, Pendidikan karakter berbasis lingkungan, dikembangkan di sekolah memiliki tujuan diantaranya agar peserta didik memilki kecintaan dan kepedulian kepada lingkungan. Adapun cara yang dapat digunakan oleh guru PAI dalam pembinaan pendidikan karakter berbasis lingkungan adalah kerja bakti lingkungan sekolah. Dan Keempat, Pendidikan karakter berbasis potensi diri. Salah satu tugas dari suatu lembaga pendidikan adalah mengkesplorasi potensi peserta didik baik yang bersifat kognitif maupun psikomotorik. Cara yang dapat digunakan oleh guru PAI dalam pembinaannya antara lain; (1) Penggunaan metode pembelajaran yang inovatif, (2) kegiatan ilmiah seperti cerdas cermat PAI, (3) Praktek materi PAI, serta (4) Ujian Praktek. Guru PAI harus sadar dan paham bahwa pembinaan tidak hanya cukup dengan perintah, tidak hanya dengan pemberian reward bagi yang menjalankan disiplin, atau pemberian punishment bagi yang melanggar, namun lebih dari itu di mana pembinaan harus dapat memunculkan kesadaran dari peserta didik itu sendiri. Ketika kesadaran sudah muncul dari dalam diri peserta didik, maka tanpa adanya paksaan darii guru, peserta didik akan dengan sendirinya melakukan kebiasaan-kebiasaan dan memiliki karakter berbasis lingkungan. Dan ditahap inilah guru dikatakan berhasil dalam pembinaan pendidikan karakter. 
Tafhim Al-'Ilmi : Jurnal Pendidikan dan Pemikiran Islam Terakreditasi Nasional SK No : 148/M/KPT/2020
ISSN: 2252-4924, e-ISSN: 2579-7182

Volume 12, No. 1 September 2020

\section{Daftar Pustaka}

Anwar, Rosihan. 2010. Akhlak Tasawuf. Bandung: Pustaka Setia

Desmita, 2012. Psikologi Perkembangan Peserta Didik. Bandung: PT. Remaja Rosdakarya

Gunawan, Heri. 2012. Pendidikan Karakter Konsep dan Implementasi, Bandung:Alfabeta

Hasbullah, 1999. Dasar-Dasar Ilmu Pendidikan, (Jakarta: PT. RajaGrafindo Persada, 1999

H.A.R Tilaar, 1990. Pendidikan Dalam Pembangunan Nasional Menyongsong Abad XXI. Jakarta: Balai Pustaka

Ki Hadjar Dewantara. 2010. Pendidikan. Yogyakarta: Majelis Luhur Persatuan Taman Siswa

Kemdiknas, 2010. Buku Induk Pembangunan Karakter. Jakarta

Khan, Yahya, 2010. Pendidikan Karakter Berbasis Potensi Diri: Mendongkrak Kualitas Pendidikan. Yogyakarta: Pelangi Publishing

Marfu, Perbedaan pendidikan karakter dengan pendidikan akhlak, pendidikan moral, dan pendidikan nilai, http:// risetpendidikangmarfu'.com, Diakses pada tanggal 20 Juli 2020.

Masganti, 2012. Perkembangan Peserta Didik. Medan: Kelompok Penerbit Perdana Mulya Sarana

Muhaimin, 2002. Paradigma Pendidikan Islam; Upaya pengefektifan PAI di Sekolah. Bandung: PT Remaja Rosdakarya

Tirtahardja, Umar, 2000. Pengantar Pendidikan Cetakan Ke-I, (jakarta: Rineka Cipta

Tarmiji, Ahmad, 2008. Meretas Jalan Sosiologi Pendidikan Ibnu Khaldun : Antara Pendidikan Karakter dan Pendidikan Nasionalisme, dalam Jurnal Komunitas Sosiologi Volume 3 No. 2 Desember. Jakarta: Jurusan Sosilogi FIS UNJ

Prahara, Erwin Yudi. 2009. Materi Pendidikan Agama Islam. Ponorogo: STAIN Po Press

Undang-Undang Sistem Pendidikan Nasional Tahun 2003 (UU RI Nomor 20 Tahun 2003), Jakarta: Sinar Grafika

Nurul Zuriah. Pendidikan Moral \& Budi Pekerti Dalam Perspektif Perubahan. Jakarta: Bumi Aksara, 2008

Yahya Khan, (2010) Pendidikan Karakter Berbasis Potensi Diri; Mendongkrak Kualitas Pendidikan, Yogyakarta, Pelangi Publishing. 